\title{
Effective Use of PBL Mode in College English Translation Teaching
}

\author{
Zhang Cheng \\ Jiangxi Police Institute; Nanchang China
}

Keywords: PBL mode; college English; translation teaching; utilization

Abstract. Nowadays with the in-depth reform college education, on the one hand, it has made significant progress in college education reform including curriculum provision, on the other hand, it allows Chinese college education to flourish which improved the excellent developing basis. Of course in China, the learning of college PBL mode, which is the trump card of students to cultivated independent thinking, plays an important role in English translation learning. With the appeared disadvantages of traditional teaching mode and other reasons, students can't attend a lecture carefully that will not only influence the arranged teaching task but also be unable to complete systematic memory. Therefore, teachers must adopt effective strategies and methods aiming at the current situation of college traditional teaching mode and accomplish the transformation from traditional mode to PBL teaching mode. The teaching staff should also make good use of PBL mode and conduct adequate research. As a consequence, this paper researched and discovered the current utilization and popularizing situation of PBL mode teaching and provided theoretical references for college English translation teaching.

\section{Introduction}

With the PBL teaching mode as a breakthrough point, this paper analyzed the advantages of the development of college PBL mode in depth as well as the problems and current situation in traditional teaching, and put forward suggestive instruction aiming at different problems from various perspective, which constantly completed the strategic and systematic thinking, helped college students establish independent thinking model and built complete PBL mode ${ }^{[1]}$. During this process, the teaching ability of college PBL mode teachers should be improved which will help them establish good training directions for students and finish the effective utilization of PBL mode in college English translation teaching.

\section{PBL mode}

Under the background of Chinese college education reform, every English teacher should put themselves in the mindset of students to do the students-centered and problem-oriented English teaching work well, set up a set pf perfect learning plan aiming at their own situation, regularly find the various teaching methods of PBL mode, establish their PBL mode independently and master a set of complete learning and researching process which can further effectively use the advantages of PBL mode in college English translation teaching [2]. During this process, teachers should establish student-centered subjective consciousness, design a set of complete scientific method of learning-situated context. What's more, starting from a driven problem, they should also provide a good platform for students to make best use of the environment and improve their own ability effectively in this link. At the same time, in order to let teachers possess relative heuristic education awareness, education trainers should provide specific training courses for teachers which makes them a good organizer and guide [3].

\section{Traditional teaching mode}

Traditional teaching mode. During the process of traditional college teaching mode, taking the college English translation teaching for example, the traditional translation education develops in monotonous form and lack contents. The cramming method of teaching which is totally outdated, is not related with hot-spot topics including the mainstream but only emphasizes the results of 
translation. The translated articles are not flexible and most of the methods have been used many years. To top it all, some students' translation only used the methods the teacher taught and there isn't any their own ways which isn't related to the real situation and lacks their own style. This kind of translation is almost the same as the translation software. If only compared with translation software, our translations are no better than the latter. Of course it can't get the good graces of other readers which will lead the abandon of traditional teaching mode gradually and the replace of PBL teaching mode [4].

The problems with the traditional teaching mode. During the process of traditionalcollege teaching mode, students always have a low efficiency after class which is caused by lack of concentration in class [5]. Therefore, many students haven't yet learned the basic skill of translation. What is reflected after class is to do the homework by using translation software optionally. This way students neither finish the task nor cultivate the bad habit of laziness in a long time. The reason is that traditional teaching method is not well suited for this new period. Education reform has always upgraded in the aspect of mode because the traditional education praised highly by many people before is not doing well in this era. On the one hand it can't finish the task, on the other hand it will delay the unfolding of the whole teaching activities, so it is not worth the candle. In order to solve the problem of low efficiency after class, we should start from the sources by using student-centered and problem-oriented PBL teaching methods.

Similarly, during the process of traditional teaching mode, there always exists the problems of ineffectiveness in preview and review. The main reasons are students didn't listen class carefully and the low efficiency after class, so they can't flexibly use the learned translation methods to do the rational thinking which makes the established thought they gained in class become an episodic memory. Every teacher should put themselves in the shoes of students, considers students' real situation to teach in accordance with students' aptitude, complete a set of perfect learning plan aiming at their real situation and regularly find the various teaching methods of PBL mode, which makes the students more motived to learn. In addition, teachers should also establish students' studying model step by step, master a set of complete learning and searching process and cultivate the habit of self-learning. Taking the college English translation teaching for example, "preview before class, review after class and examination" circulation teaching method can highlight the students-centered and teacher-oriented subject consciousness.

\section{The effective use of PBL mode in college English translation teaching}

Cultivating students interests of translation. In the real teaching work, aiming at college students' low efficiency in class, teachers should attract students' attention in class and pay attention to interest-guiding. Every teacher should put themselves in the shoes of students, considers students' real situation to teach in accordance with students' aptitude, which makes the students more motived to learn. In addition, teachers should also establish students' studying model step by step, master a set of complete learning and searching process and cultivate the habit of self-learning. Taking the college English translation teaching for example, "preview-review-examination" circulation teaching method can highlight the students-centered and teacher-oriented subject consciousness. Last but not least, teachers should regularly find the various teaching methods of PBL mode which will ensure every student find their advantages and be themselves. Only this way students can devote themselves in making contribution to the society.

Confirming the student-centered subjective consciousness. Aiming at the problem of low efficiency in class, the inattention in class should be paid attention to. Taking the college English translation teaching for example, "preview-review-examination" circulation teaching method should be used. In the perspective of teachers, they should give students a specific arrangement of pre work and supervise them constantly. In this way, students can have a general direction and purpose of knowledge and it is helpful for the further study. Going round and round, teachers should not only play a supervision role, but also play the role of a guide, leading the students to think problems sufficiently, figuring out the students-centered subjective consciousness and making them create their 
own ways to solve the problem. Last but not least, in the purpose of emphasizing active-learning, it is important to mobilize students' initiative and enthusiasm and use driven-problem-oriented way to complete heuristic education. In addition to this, teachers should pay attention to the encouragement and praise of students' behavior in class which will improve their confidence and courage.

Establishing problem-oriented contextual model. In order to establishing problem-oriented contextual model, many effective teaching methods can be used and it will further improve students' learning enthusiasm. Taking college English translation learning for example, this way can foster interest of students in translation, especially in the stage of freshman, which is the case-hardened and critical period. Therefore, problem-oriented, not teaching-oriented contextual model should be established. If teachers always teach the students results rather than the way of solving problems, there are differences between the teaching methods. Thus only the teachers follow the course of time, transform their teaching thought and habits and pay attention to foster students' learning interests, can students really full in love with PBL mode [6]. The effective teaching methods are group work and independent learning. This way a lot of important advantages which can improve their social communication ability, learn the way how to communicate with others, make PBL mode more intuitive and vivid and set many contextual models which makes students go into the environment and foster their interest in translation.

Making best use of PBL mode in college English translation. Under the background of college education reform, teachers should fully exploit the students' potentialities through practical activities, motivate students' emotion, improve the teaching of PBL mode, strengthen the cultivation of self-learning ability and pay attention to the effectiveness of teaching [7]. In all ages, teaching activity is a kind of knowledge. Every teacher should carry on the thorough analysis and researches, establish a series of regular activities, improve dynamic translation period, enhance micro communication between each side, find and innovate problem-oriented teaching methods, adopt various teaching methods to generate passion of learning and build easy and active learning environment for students which realizes the high efficiency class [8]. Students should also turn passive language study into active application from themselves as well as complete a set of perfect learning plan of their own. At the same time, teachers should regularly find the various teaching methods of pragmatic adaptation theory which can make students generate learning motivation, establish their learning model step by step and master set of complete learning and researching process. Therefore, PBL mode can be made best use in college English translation education.

\section{Conclusion}

Generally speaking, this paper researched and discovered the current problems of college traditional mode teaching and provided theoretical references for the teaching of PBL mode. Nowadays with the in-depth reform college education, on the one hand, it has made significant progress in college education reform including curriculum provision, on the other hand, it allows Chinese college education to flourish which improved the excellent developing basis. During this stage, "preview-review-examination" circulation teaching method should be used and student-centered and teacher-oriented subjective consciousness should be emphasized. Therefore, teachers must adopt effective strategies and methods aiming at the current situation of college traditional teaching mode and complete the transformation from traditional mode to PBL mode. Every college teacher should make use of PBL mode, which can provide theoretical references for college English translation teaching.

\section{References}

[1]Cheng Hongmei. The application of PBL mode in college English teaching under internet environment [J]. Hebei Engineering University Journal (Social Sciences), 2015, 32(2):127-128.

[2]Chen Haiyan. Research of the application of PBL learning method based on projects in college English teaching [D]. Shandong Normal University, 2012. 
[3]Long Manli. Practice research of PBL teaching mode in college English class under TPACK framework [J]. Overseas English, 2016(13):3-4.

[4]Yi Bo. Application research of PBL mode in the teaching of art university English classes [J]. Education Science \& Culture Periodical, 2015(27):168-169.

[5] Yi Bin. Application of PBL mode in university information quality teaching [J]. Library Work and Study, 2008(10):95-97.2014(9):61-62.

[6]Yao Li, Jin Qiuyue, Shi Na etc. Discovery of biochemistry teaching based on PBL mode [J]. Progress in Modern Biomedicine, 2010, 10(24):4761-4763.

[7]Wang Yuxi. Thinking of several problems of college English translation teaching [J]. Chinese Translation, 2010(6):29-33.

[8]Liu Ying. College English translation teaching: Review, Thinking and Outlook [J]. Guangxi College Education Journal, 2014(2). 